\title{
Stat op i Gry, min Gud! \\ Tre gammeltestamentlige salmer, gendigtet af Grundtvig.
}

\author{
Af Else Kragelund Holt
}

De følgende overvejelser over forholdet mellem nogle gammeltestamentlige salmer og Grundtvigs gengivelse deraf har ikke deres udgangspunkt i Grundtvig-forskningen. De iagttagelser, der gøres, vil ikke blive set i forhold til Grundtvigs biografi, eller hans teologiske eller homiletiske udvikling, skønt sådanne indfaldsvinkler må formodes at kunne bringe spændende indsigter. Som ekseget tager jeg derimod mit udgangspunkt i Det gamle Testamente, og opgaven er at gøre nogle basalt set eksegetiske ${ }^{1}$ - traditionshistoriske eller interpretationsskritiske - overvejelser over forholdet mellem forlæg og genlæsning i nogle få af de salmer, Grundtvig skrev på grundlag af gammeltestamentlige salmer. Det drejer sig altså ikke primært om at sammenligne Grundtvigs gendigtninger med den for ham foreliggende oversættelse, men om en sammenligning af salmerne i den form, de har i den gammeltestamentlige tekst, som den foreligger i Biblia Hebraica $^{2}$, og den form, som de får hos Grundtvig. Sigtet er altså mere nutidigt, praktisk-teologisk, end historisk. Alligevel vil det også være nyttigt (og nødvendigt) kort at sætte Grundtvig-salmerne ind i deres egen praktisk-teologiske sammenhæng.

Materialet stammer fra Sangværkets første bind ${ }^{3}$. Grundtvigs idé med sit Sangværk var at forny den danske salmesang, slet og ret. Dette skulle, foruden ved en gennemskrivning af ældre danske salmer, ske ved en fordanskning af ikke alene ældre lutherske, men også latinske salmer; og også de andre syv »folkemenigheders « salmer skulle inddrages. Det var ikke Grundtvigs hensigt så meget at være original som netop at gøre denne kirkelige sangskat tilgængelig for den danske menighed. Han betegner selv, i et brev til Ingemann i september 1837 Sangværket som en »... Sammensmeltning af Toner fra alle Hovedgangene i den almindelige Kirke.« Dog må netop Grundtvigs arbejdsform betinge, at $» \ldots$ de forskjellige Toner ved at gaa igjennem mig har tabt meget af deres Ejendommelighed... « ${ }^{4}$

I Sangværket finder vi de enkelte folkemenigheders salmer i en stadig gentagen rækkefølge: den hebraiske, som især repræsenteres af Davidssalmer, den græske, den latinske, den engelske, den tyske og 
den danske. Hertil lægger sig som det syvende led originale Grundtvig-salmer, hvilket for nogle har antydet, at Grundtvig opfattede sig selv, og måske Ingemann, hvis salmer er flettet ind blandt hans egne, som den syvende folkemenighed.

Om denne komposition siger Jørgen Elbek i sin bog Grundtvig og de graske salmer: »Kompositionen udtrykker [Grundtvigs] opfattelse af kirken som et universelt samfund, der er spaltet, ikke i konfessioner, men i folkemenigheder.« Og Elbek kan konkludere, at Sangværket har »en dobbelt baggrund: dels en følelse af, at det blot protestantiske er utilstrækkeligt, dels en overbevisning om, at kirken og folkemenighederne er ét. « Sådan er altså Grundtvigs teologiske udgangspunkt, og det er på denne baggrund, man skal forstå hans interesse $\mathrm{i}$ at gendigte gammeltestamentlige salmer.

Man kan betragte de følgende overvejelser som en art grundanalyse af forholdet mellem de gammeltestamentlige salmer og deres moderne genbrug. Der skal derfor ikke tales generelt; jeg vil gribe fat $\mathrm{i}$ nogle få enkeltsalmer og se først på deres form og indhold i Det gamle Testamente og dernæst på den brug, Grundtvig gør deraf. Valget er så faldet på tre salmer, der hører til påskedelen af Sangværket, SV 206: I de gyldne Himmel-Sale, »Efter den 16de Davids-Psalme«; SV 207, O, Gud, min Gud og Fader! »Den 22de Davids-Salme, frit oversat « og endelig SV 209: Stat op i Gry, min Gud! stat op. Af disse hænger de to første sammen med gammeltestamentlige tekster, der nu er læsetekst efter Alterbogen af 1992, og den sidste har i den gendigtede form fået sin ganske naturlige placering i påskegudstjenesternes salmesang, hvor den på forbilledlig vis viser en bibelsk-teologiskhomiletisk sammenhæng mellem Det gamle og Det ny Testamente.

\section{SV 206 - I de gyldne Himmel-Sale}

I de gyldne Himmel-Sale er altså if. Sangværket »Efter den 16de Davids-Psalme.« Denne gammeltestamentlige salme bestemmes formkritisk som en tillidssalme, dvs. en salme, der udtrykker en ubekymret tillid til, at Herren sørger for sine, mens det modsat retfærdigvis går de ugudelige slet. Den har således også et umiskendeligt præg af den såkaldte visdomstænkning, kendt bl.a. fra Ordsprogsbogen. Salmen indledes med en bøn: »Vogt mig, Gud, jeg søger tilflugt hos dig« (v. 1), som måske nok kunne få én til at tro, at der var tale om en klage- 
salme; men hovedtonen i salmen er i фvrigt tilliden til Gud. Salmisten præsenterer sig selv som en person, der er absolut trofast overfor Gud: Jeg siger til Herren: »Du er min herre, ingen anden end du er min lykke« (v. 2), og han ser sig selv som stående i modsætning til de ikke-troende: De, som løber efter andre guder, rammes af mange lidelser (4a). Som løn for denne trofasthed modtager han det rige, velsignede liv:

Herre, du min tilmålte del og mit bæger, du sikrer min lod.

Målesnorene tildelte mig herlige steder,

jeg kan fryde mig over min ejendom (v. 5-6).

Alt dette ligger vel en moderne læser lidt fjernt. Den tilsyneladende selvros finder vi lidet kristeligt-ydmyg, og deri har vi jo da også ganske ret. Men fremstillingen af den syngendes retfærdighed har haft $\sin$ helt naturlige plads i Jerusalems tempel i den sene kongetid, hvorfra denne salme sandsynligvis stammer. Den, der var retfærdig, kunne - og burde - frimodigt stå frem i templet og synge sin takkesalme til den Herre, der havde skænket ham alt.

Salmens anden halvdel, v. 7-11, er det nemmere umiddelbart at synge med på. Her fremføres netop en taksigelse for den guddommelige vejledning, som var forudsætningen for, at salmisten faktisk lever som retfærdig. Dag og nat modtager han Herrens råd og vejledning; altid går han ved hans højre side, så han ikke vakler; altid leder og underviser Herren ham; og derfor er hans hjerte fuldt af jubel. Ja, Herren er med ham, så han ikke skal $\mathrm{d} \varnothing$ før tiden:

du vil ikke prisgive mig til dødsriget,

din fromme vil du ikke lade se graven (v. 10).

Man kunne således nok mene, at Grundtvig kunne have brugt anden del af S1 16 temmelig umiddelbart om den glade, grundtvigske kristnes fryd ved livet.

Men det er slet ikke, hvad han gør. For at forstå, hvad Grundtvig foretager sig, må vi gå en kort omvej ad Biblens oversættelses- og udlægningshistorie op til 1800-tallet. Grundtvig må, i hvert fald i 1837, have brugt Christian VIs Bibel, formodentlig i den reviderede udgave fra $1759 .{ }^{6}$ Denne var, som også tidligere bibeludgaver, forsynet med indledende summarier og tekstnoter, der skulle sikre den rette forståelse af teksten. Summarierne var udtryk for en klassisk 
opfattelse af kanon, hvor Det gamle Testamente læses, ikke med det moderne slagord: på dets egne betingelser, men som traditionen byder det som Vetus Testamentum in Novo receptum, altså som en profetisk forudgribelse af evangeliet. Ord som »Christus«, »Christi rige« og »prædicken « er almindelige, fx i summarierne til Salmerne. ${ }^{7}$

Formodentlig inspireret af summariet i Christian VIs Bibel gengiver Grundtvig i SV 206 som en slags teater en scene mellem Gud Fader og Sønnen »I de gyldne Himmel-Sale«. Her fører de to en samtale, som Grundtvig lader os lytte til. Aandernes og St $\varnothing v e t s$ Fader rådslår med Sønnen, Herren, om, hvordan mennesket kan frelses. Faderen trænger til Sønnens hjælp:

Helgen-Folket i det Lave

Kan ei frelses, uden Du

Underfuld dem vil begave

Med min Lyst i Sind og Hu,

Daarlig deres Sag de stiled,

Sørgelig sig overiled,

Sank til Jord i Afmagt ned! (strofe 3)

Sønnen skal fjerne blodskylden fra menneskene, så de kan bænkes hos Gud i himlen:

Du kun er min Arv, mit Bæger,

Herre, Du Mig vederkvæger,

Du gienløser Mig mit Folk. (strofe 4)

Det er i denne sammenhæng, der citeres fra S1 16. Således strofe 5:

Ja, Jeg forudseer i Aanden,

Herre, Dig ved Høire-Haanden,

Hjelper min og Støtte-Stav!

Hvor det i S1 16 var Gud Herren, der var menneskets støtte, bliver det hos Grundtvig til en forudsigelse af Herren Kristus som st $\varnothing t t e$ for Gud Faders frelsesprojekt. Vi finder altså en klart profetisk brug af det gammeltestamentlige forlæg. Og denne fortsætter i strofe 6. Her skifter den talende person fra Faderen til Sønnen; Jesus tager ordene fra Sl 16 i munden og priser Faderen for den velgerning, som han véd, han vil vise ham, når han om kort tid skal gå ind til sin frelsergerning. I Sl 16,9-10 hedder det: 
Derfor glæder mit hjerte sig, og min sjæl jubler, ja, mit legeme skal bo i tryghed.

For du vil ikke prisgive mig til dødsriget,

din fromme vil du ikke lade se graven.

Disse ord bliver i Jesu mund til en forudsigelse af sejren over dødsriget og af opstandelsen - en sejr, der, bemærker man, sker ved Faderens hjælp:

Sønnen svarer: Fryd og Glæde

Gløder, synger i mit Bryst,

Tungen skal din Priis og kvæde,

Du i Kiødet er min Trøst,

Ei min Sjæl i Hel Du glemmer,

Lader ei din Helgens Lemmer

See Forraadnelse i Grav! (strofe 6)

Sl 16,11:

Du lærer mig livets vej,

du mætter mig med glæde for dit ansigt,

du har altid herlige ting $\mathrm{i}$ din højre hånd,

bliver tilsvarende til en forudsigelse af Sønnens himmelfart og kongegerning i Himlen:

Giennem Dødens Skygge-Dale

Du har viist mig Livets Sti,

Saa i dine gyldne Sale

Atter glade mødes $\mathrm{Vi}$,

Mætte vil Du mig med Glæde,

Skikke lystelig til Sæde

Evig ved din Høire-Haand! (strofe 7)

Sammenfattende kan man i SV 206 iagttage, hvordan Grundtvig genanvender et motiv, tilliden til Herrens førelse, fra Davidssalmen, men giver det en ganske anden kontekst. Sl 16 bevæger sig på det rent jordisk-materielle plan. Salmisten fryder sig i v. 6 over de »herlige steder «, Herren har udmålt til ham og fryder sig over sin ejendom; på denne baggrund priser han da Herren for hans førelse af ham i livet. Men hvor Si 16 er jordisk orienteret, bliver perspektivet hos Grundtvig kosmisk. 
Og, kunne man tilføje: gudstjenesteligt. Det kan ganske vist hævdes, at »I de gyldne Himmel-Sale « ikke er egnet som gudstjenestesalme, ja at den måske i virkeligheden slet ikke er en salme. Måske er Grundtvigs projekt simpelthen bibelsk-teologisk en tand for frækt for det moderne menneske; Grundtvig er jo lige ved at opføre sig som en rigtig, nytestamentlig evangelist ved at lægge Faderen og Sønnen gammeltestamentlige ord i munden. Men på den anden side: Når man i kirken 2. påskedag efter 2. tekstrække indleder sin gudstjeneste med at læse Sl 16,5-11, er det så blot, fordi denne salme på en flot måde udtrykker jubel over Guds vejledning, og fordi den så tilfældigvis siger, at den syngende ikke skal dø for tidligt eller forkert, sådan som det oprindeligt var meningen i den gammeltestamentlig salme? ${ }^{8} \mathrm{Nej}$, det er netop, fordi salmens ord får en ny valeur: »Jeg skal ikke for evigt prisgives til dødsriget « gennem den frelsergerning, som Grundtvig taler om i sin salme.

Tilsvarende er SV 206 ikke udtryk for en gendigtning, men for en re-interpretation af den gammeltestamentlige tekst. Den implicitte tid i Grundtvigs tekst er forud for Kristi frelsesgerning; gudstjenestens brug af S1 16 ligger efter; men forkyndelsessigtet i de to anvendelser er det samme.

\section{SV 207 - O, min Gud, min Gud og Fader!}

Den optimistiske og glade tone i SV 206, »I de gyldne Himmel-Sale « står i et krast spændingsforhold til den følgende salme, SV 207, O, min Gud, min Gud og Fader! »Den 22de Davids-Psalme, frit oversat.«

Det har naturligvis sine gode grunde. Salme 22 har sin ganske særlige placering i den kristne bevidsthed, thi det er den, der indledes af Jesu korsord: 'élî, 'élî lāmā 'a zabtānî - Min Gud, min Gud! hvorfor har du forladt mig? (Sl 22,1), og vi har en fornemmelse af ud fra disse ord at kende denne individuelle klagesalme. Jeg skal ikke gennemgå den i detaljen, men blot give en kort oversigt over salmens genre og opbygning som baggrund for sammenligningen med Grundtvigs salme.

Sl 22 er af formkritikken bestemt som en individuel klagesalme. v. 2-22a indeholder den fortvivlede klage fra én, der finder sig forladt af Gud: 
Min Gud, min Gud! Hvorfor har du forladt mig?

Du er langt borte fra mit råb om hjælp og fra mit skrig.

Min Gud, jeg råber om dagen, men du svarer ikke,

og om natten, men jeg finder ikke ro. (v. 2-3)

Salmen fortsætter derefter med afvekslende at tale om Guds styrke, hans trofasthed og førelse af salmisten og hans folk, og med salmistens klageskrig. V. 4-6 beskriver den hellige Gud som Israels hjælper; heroverfor står i v. 7-9 beskrivelsen af salmisten som den, der er til spot på grund af denne tro. De spottende anser tydeligvis ikke Herrens hjælp for noget værd.

V. 10-12 appellerer til Gud: »... fra moders liv var du min Gud. Hold dig ikke borte fra mig...; « v. 13-19 beskriver den nød, salmisten befinder sig i. I et billedrigt sprog beskriver han sin tilstand; omgivelserne er alle imod ham:

Stærke tyre omgiver mig,

Bashanbøfler omringer mig;

rovgriske og brølende løver

spærrer gabet op mod mig (v. 13-14).

Og v. 17-19:

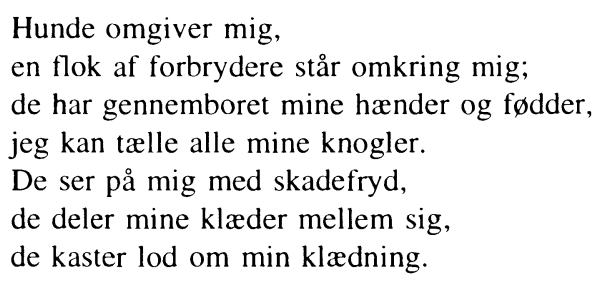

Salmisten er trængt fra alle sider. Han er sat uden for samfundet, det sociale fællesskab, som var langt mere afgørende for den tids menneske, end det er i dag. Den person, der her klager til Gud, er ikke et moderne menneske, der ser sig selv som først og fremmest et uafhængigt, selvstændigt individ. Den klagende er den, der ser sin eksistens, sit liv, som totalt afhængigt af fællesskabet med Gud $o g$ med mennesker. Dette fællesskab er han afskåret fra. Isolationen fra samfundet opfatter han som udtryk for, at han er isoleret fra Gud.

Derfor går hans liv i stykker, i opløsning. Man skal være forsigtig med at tolke tekster så fjerne fra vor tid og tænkemåde som de gammeltestamentlige i psykologiske kategorier. Men det sprog, salmisten 
anvender, når han skal beskrive sin tilstand, giver med sin blanding af billeder og konkret beskrivelse, en prægnant fremstilling af en person i både sjælelig og legemlig opløsning:

Jeg er som vand, der hældes ud,

alle mine knogler falder fra hinanden,

mit hjerte er som voks,

det smelter i livet på mig.

Min gane er tør som et potteskår,

min tunge klæber til gummerne,

du lægger mig i dødens støv (v. 15-16).

Det er et udsagn, der først og fremmest skal høres og forstås med hjertet og med maven.

Salmens første del slutter da med salmistens gentagne, indtrængende bøn om, at Gud vil komme ham til frelse.

Herefter sker der et absolut omslag i salmen. »Du har svaret mig!«, siges det (v. 22b), og salmisten fortsætter med en jublende lovprisning af sin frelses Gud, der »... hørte, da han råbte om hjælp « (v. 25b). Hvad det er, der rent historisk har udløst udråbet: »Du har svaret mig!« og den påfølgende jubel, kan vi ikke vide med sikkerhed. Den almindelige opfattelse i forskningen er den, at den klagende har modtaget et frelsesorakel fra Gud, fremført af en tempelpræst eller -profet, og reagerer herpå.

Hvorom alting er, slutter $\mathrm{Sl} 22$, som så mange andre af de såkaldt individuelle klagesalmer, med salmistens taksigelse. Denne er i Sl 22 bl.a. udformet som en forkyndelse af en universel tilbedelse af Herren Jahve: De fremmede folkeslag skal tilbede kongen Jahve; de døde i dødsriget skal kaste sig ned for ham - »Men selv vil jeg leve for ham, og mine efterkommere skal tjene ham « - hans retfærdighed skal forkyndes for folk, der fødes, »for han greb ind!« (v. 29-32).

Venter man nu, at Grundtvig i sin brug af Sl 22 med hele dens passionskonnotation vil gribe tilbage til Jesu korsord eller tolke klagen kristologisk; at han måske vil tage fat $\mathrm{i}$ ordene i v. 19: »de deler mine klæder mellem sig, de kaster lod om min klædning«, som spiller så stor en rolle i Matthæus- og Johannespassionen; at han, som i den foregående salme læner sig op ad udlægningen i rubrikken $i$ Christian VIs Bibel; at Grundtvig med andre ord her vil skrive en salme, som burde kunne synges som meditation ved langfredagsgudstjenesten også i dag - ja, så tager man fejl. 
SV 207, »O, min Gud, min Gud og Fader!« er ikke som SV 206 »efter den 16de Davids-salme«, men derimod »den 22de Davids-salme, frit oversat «, altså ikke en genlæsning, men en oversættelse. Grundtvig holder sig trofast til sit forlæg. Det er, som om det her har været meningen simpelthen at gøre Sl 22 syngelig i menigheden. Det er ikke primart en gammeltestamentlig salme, kristeligt forvendt. Sammenlign blot Sl 22,3-6 med SV 207, 2-3. Her ses det tydeligt, hvor tekstnært Grundtvig arbejder:

3 Min Gud, jeg råber om dagen, men du svarer ikke,

og om natten,

men jeg finder ikke ro.

4 Du troner som den hellige, du, som Israel lovsynger,

5 Vore Fædre stolede på dig, de stolede på dig,

og du udfriede dem.

6 De klagede til dig

og blev reddet,

de stolede på dig

og blev ikke gjort til skamme.
(2) O, kan Du dog ei høre, Jeg raaber Dag og Nat?

Nei, Du har intet Øre

For mig, i Nød forladt,

Skiønt Vidnesbyrd langt bedre

Dig gav de gamle Fædre,

Du Miskundhedens Gud!

(3) Da holdt Du Dig ei fremmed,

Hvor Hjertet sig udgiød,

Du Haabet ei beskiæmmed

Men frelste brat af Nød;

Det betyder naturligvis ikke, at der ikke falder Grundtvig kristen terminologi i pennen. Det sker bl.a. i de flg. to eksempler:

\section{v. 22 Jeg vil forkynde dit navn \\ for mine brødre, \\ i forsamlingens midte \\ vil jeg lovprise dig.}

\section{v. 26 Du er min lovsang} i den store forsamling,

jeg indfrier mine løfter for øjnene af dem, der frygter Herren.
(11) Da vil dit Navn jeg mindes

i Brødre-Flokken stor, da skal din Lovsang findes hos mig i Kirke-Chor (min fremhævelse).

(13) Nu vil jeg Gud betale De Løfter, jeg har gjort, Og lydt fra Kirke-Svale, i Selskab saare stort (min fremhævelse).

Sådanne aktualiseringer er ikke udtryk for en egentlig ændring af forlægget. Det er på en anden måde, man mærker en glidning hos Grundtvig, en personlig bearbejdelse af Sl 22. Denne ligger i flere ting, der på ganske subtil vis sætter sit præg på hans oversættelse. Det første, der skal nævnes er, at den Gud, Grundtvig taler til, er Gud Fader. Billedet af Gud som Fader er ikke fremmed for Det 
gamle Testamente; men det findes næsten ikke i Salmernes Bog. Og i hvert fald er det helt fraværende i Sl 22. Hér er det Israels stærke Gud, Verdens konge, der tales til. Men Grundtvig indleder sin gendigtning med ordene: »O Gud, min Gud og Fader." Jeg tror, at man her kan spore den påvirkning fra Jesu korsord, som ellers synes påfaldende fraværende i gendigtningen. Når Grundtvig i det $\varnothing$ vrige ligger så tæt på forlægget, er der da anden forklaring på afvigelsen end allusionen til passionsberetningen?

Faderbilledet dukker op igen i salmens anden del, taksigelsen fra strofe 13:

$\mathrm{Nu}$ vil jeg Gud betale

De Løfter, jeg har gjort,

Og lydt fra Kirke-Svale,

i Selskab saare stort

Blandt alle dem, Ham frygte,

Hans gode Fader-Rygte

Udbrede med min Sang!

Heller ikke hér er der antydning af faderskikkelse i forlægget, som ellers følges ganske nøje.

At passionen er baggrunden for Grundtvigs salme, ser vi også i strofe 1. Sl 22,2 siger: »Min Gud, min Gud! Hvorfor har du forladt mig?«; men Grundtvig beder:

O, Gud, min Gud og Fader!

$\mathrm{O}$, bliv dog hos mig nu!

O vee, Du mig forlader,

Mig kommer ei ihu! (min fremhævelse)

I hvert fald for den umiddelbare betragtning ser det ud, som om den bedende her ikke allerede $e r$ forladt, men frygter at blive det, ja véd, at han vil blive forladt. Som Jesus bad i Gethsemane have Skærtorsdags aften, men måtte indse, at den endelige forladthed skulle blive ham til del, sådan beder den syngende her i salmen med fortvivlelsens mod - blot for at indse, at det intet nytter. Allusionen til påskeangsten er tydelig, men den er både til Langfredags nødråb på korset $o g$ til dødsangsten Skærtorsdag.

Men salmen tager ikke det typologiske skridt fuldt ud, som det gøres, når S1 22 læses i kirkens langfredagsgudstjeneste. Det er ikke Jesus selv, der synger. Salmen alluderer til Jesu angst og hans abso- 
lutte forladthed på korset; men det er en angst og en gudsforladthed, der hviler på et dødeligt menneske. Det understreges af salmens $\emptyset$ vrige indhold, både hvor det ligger forlægget nær, og hvor vi finder forskel på forlæg og gengivelse.

En sådan forskel finder vi umiddelbart efter nødråbet i Grundtvigsalmens begyndelse. Salme 22 er en af de individuelle klagesalmer, der på den ene side ikke indeholder nogen syndsbekendelse, men som på den anden side heller ikke understreger uskyldigheds- eller fromhedsaspektet hos den klagende særligt kraftigt. Det er, som om salmisten står ganske passiv i de begivenheder, den tilstand, han klager over.

Anderledes hos Grundtvig. Første strofe lyder i sin helhed:

O, Gud, min Gud og Fader!

O bliv dog hos mig nu!

O vee, Du mig forlader,

Mig kommer ei ihu!

O, Gud! hvor jeg er bange!

Det er de Synder mange,

Som skille vidt os ad!

Hvor israelitten kan klage over den meningsløse tomhed, Guds meningsløse fravær, dér er (den lutherske?, den pietistiske? den kristne?) Grundtvig nødt til at finde én eller anden grund til, at Gud er ham så fjern: »Det er de Synder mange, som skille vidt os ad.«

Menneskets synd stiller sig i vejen for det umiddelbare forhold mellem Gud og menneske. Og omverdenens afstandtagen, som i Sl 22 var tegn på Gudsforladtheden, bliver her til dens spot over denne Gudsforladthed. Den omverden, der i Sl 22,9 tvivlede på Herrens magt eller hele eksistens, den omverden, der altså kunne betegnes som ugudelig, denne omverden tvivler hos Grundtvig ikke på Guds eksistens, men på, at Hans kærlighed kan gælde den syngende. Heri består for mig at se en radikal forskel.

Vi så tidligere, at stemningsbruddet $\mathrm{i}$ den gammeltestamentlige salme sker ganske pludseligt, som efter en forkyndelse af Guds velsignelse over den klagende. Denne velsignelse står ikke nedfældet i salmens tekst, og teorien om et præsteligt orakel var ikke udkastet på Grundtvigs tid. For Grundtvig har det pludselige omsving altså været lige så mærkeligt som for den læser, der i dag læser Sl 22 første gang, og Grundtvig har måttet arbejde intenst med dette omslag for at få det til at give mening. 
Overgangen sker i Sl 22,20-22 og SV 207, strofe 10:

Men du, Herre, hold dig ikke borte,

du, min styrke, skynd dig til hjælp!

Red mit liv fra sværdet,

mit dyrebare liv fra hundene,

frels mig fra løvens gab,

fra vildoksernes horn!

- eller som der står i Christian VI-biblen:

»fra eenhiørningers horn«
O, Gud! kom fra det fjerne!

Kom til min Bistand nær!

Thi kløve vil min Hjerne

Den grumme Fiendes Sværd,

O, frels mig fra den Tørning

Med Løve og Enhjørning!

$\mathrm{O}$, frels min arme Sjæl!

Der er nær overensstemmelse mellem de to bønner; men én ting forekommer mig påfaldende. Hos Grundtvig er der ikke tale om et ubestemt sværd, men om den grumme fjendes svard, en fjende, der kun kan være Døden selv. Denne billedbrug underbygges ganske stærkt af fortsættelsen, bønnen om at måtte frelses fra kampen mod løve og Enhjørning, dette tvetydige fabeldyr, der ganske vist i den middelalderlige symbolverden repræsenterer renhed og jomfruelighed, når den endda ikke er billede på Kristus selv, men som her, sammen med løven, udtrykker den utæmmelige vildskab - en enhjørning kan if. legenden kun fanges, hvis den lægger sit hoved i en ren jomfrus skød. Er løven og enhjørningen mon ikke også billeder på Døden og Djævelen, fra hvem den arme sjæl må frelses af den Gud, der skal komme fra det fjerne?

Side om side i Sangværket står disse to salmer som de første i påskedelen. Denne begynder ganske vist egentlig med SV 205, Al den ganske Christenhed priser Guds Barmhjertighed. I den afspejles overgangen fra juleglæden til påskens begivenheder ved en gendigtning af Es 53, sangen om Herrens lidende tjener. Men de egentlige påskesalmer er, tror jeg, for Grundtvig altså den salme, der tolkes om den frelsergerning, som Herren Jesus vil foretage, nemlig SV 206, og den salme, SV 207, som det angste menneske må synge sammen med den korsfæstede.

Efter disse to salmer følger SV 208, Op til J e r u s a le $m$ vi gaae, med forlæg, som det hedder i en "grask Faste-Sang «, og hér ender passionsdelen. For derpå følger SV 209: Stat op $i$ Gry, min Gud! stat op, der med Grundtvigs egne ord er »Den 68de DavidsPsalme, christelig benyttet. « Her finder vi altså en klar hensigtserklæring allerede i noten. 
SV 209 - Stat op i Gry, min Gud! stat op!

Sl 68 er en vældig krigshymne, en lovprisning af Sinajs Herre, Israels Gud, ham der skaber frugtbarhed og tryghed i landet, faderløses fader og enkers forsvarer. Men også ham, hvis »stridsvogne er to gange ti tusind, tusinder og atter tusinder « (v. 18). Han er den Gud, der »knuser sine fjenders hoved, issen på dem, der lever i skyld« (v. 22). Han er den, der henter Israels fjender ned fra det højeste bjerg og op fra havets dyb, »så du kan bade dine fødder i blod og dine hunde få deres del af fjenderne« (v. 24).

Samtidig er det en lovprisning af skaberguden, her ikke fremstillet som ham, der skabte himlen og jorden, men som sagt som ham, der skaber gode livsbetingelser for sit folk, Israel. Det sker både ved, at fjenderne overvindes og ved, at folket førtes gennem det $\varnothing$ de land på dets vandring fra Ægypten:

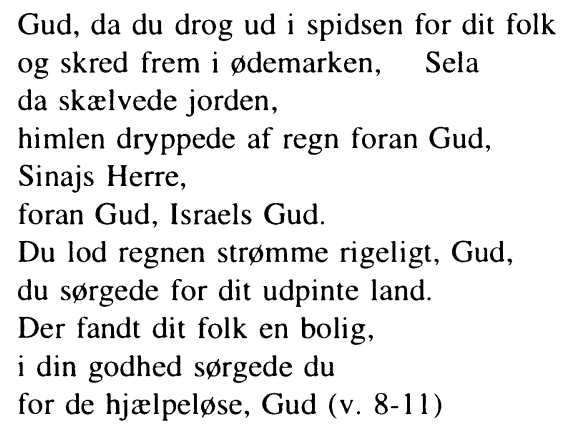

Måske har vi i denne salme en af de salmer, der blev sunget når arken (den sejrrige Jahves symbol ved den store nytårsfest i før-eksilsk tid) blev bragt ind i Jerusalems tempel. Hér er skælvende fjender, her er den Gud, der førte sit folk i ødemarken, her er festtoget til helligdommen med sangere, strengespillere og i midten de unge piger, der slår pauken. Her er festjubel over hele linjen og her er opfordringen til Gud:

Opbyd din styrke, Gud,

den styrke, Gud, du har vist os,

fra dit tempel i Jerusalem;

konger skal bringe dig gaver (v. 29-30) 
En anden mulig datering og Sitz im Leben, som må tages under overvejelse er, om salmen slet ikke er så gammel, som man skulle tro, når man først gang læser den $\mathrm{i}$ hele dens martialske vælde og begejstring. For netop det førnævnte element, lovsangen for den Gud, der førte sit folk til det frugtbare land, kunne pege på en sammenhæng med de tanker om folkets hjemvendelse gennem ørkenen, som vi finder hos Deuterojesaja, profeten, der digter om folkets hjemvendelse fra det babyloniske eksil, og som vi møder i Es 40-55. Er den dét, er det en salme, der synges på trods af de faktiske forhold $\mathrm{i}$ Jerusalem, denne ødelagte by, hvor også templet var blevet nedbrændt af den babyloniske hær i 587 f.Kr. Men så er det samtidig en salme, der netop skal synges på trods, med håb og tro på, at alt kan blive godt igen. Jerusalems tempel vil atter kunne være Guds bjerg, hvortil Judas stammer kommer i festtog, men også det tempelbjerg, hvor alle jordens andre konger skal bringe Israels Gud deres overgivelsesgaver.

Det er muligt, at denne sidste opfattelse, at salmen er skrevet i efter-eksilsk tid, ikke holder for en nærmere afprøvning. En tredje mulighed må derfor overvejes, nemlig at vi i Sl 68 finder udtryk for en intertekstuel interpretation. Man taler i salmeforskningen i disse år en del om genlaesning inden for teksterne selv, altså det fænomen, at en ældre salme er overleveret til os i en form, der er bearbejdet af senere brugere. Der er ikke så meget tale om egentlig redaktion, som om at en tekst - og det er typisk en salme - bliver aktualiseret for at kunne anvendes meningsfuldt under de fornyede livsbetingelser under og efter genopbygningen af Jerusalem og templet. Dette fænomen kan med stor sikkerhed eftervises andre steder i Salmernes Bog, fx Sl 50 og 51, og måske finder vi det også hér. Det ville forklare den egentlig gnidningsløse sammenstilling af temaer, som vi ellers daterer som typiske for forskellige perioder i Israels historie.

Under alle omstændigheder er salmen blevet sunget og overleveret i efter-eksilsk tid og har givet god mening. Det giver derfor også teologisk god mening at overveje, hvor langt der metodisk set er fra den bibelske genlæsning og formodentlige reinterpretation til Grundtvigs og dermed den nuværende kristne menigheds brug.

Afstanden er ikke stor. For atter er Grundtvig, når han tolker S1 68 kristologisk, i samklang med summariet i Christian VIs Bibel. Her parafraseres også S1 68 nemlig netop som en Kristus-profeti. Det hedder: 
»David spaaer om Messiæ Majestætiske og trøstefulde tilkommende, 2-7. Om evangelii herlige prædiken, 8-17. Om Messiæ prægtige himmelfart, 18.19; Om hans riges beskaffenhed og udbredelse v. 20-36.«

Den Gud, vi møder i S1 68, er den mægtige gudekonge. Og den samme konge er det, Grundtvig digter om. Der er langt fra ham til den Kristus, der byder at vende den anden kind til. Her er der tale om den samme sejrrige Kristus, som vi kender fra SV 219, Herren af Søvne opvaagned, opsprang, der er bygget over et græsk forlæg. Det er ganske tydeligt, at vi her for Grundtvig befinder os inden for ganske den samme billedverden. Derfor er Grundtvigs etikette, »Den 68de Davids-Psalme, christelig benyttet« også ganske præcis. Man kan ved at sammenligne de to salmer, den gammeltestamentlige og Grundtvigs, strofe for strofe se, at Grundtvig følger Det gamle Testamentes tekst ganske tro. Lad os til illustration se på de første par strofer:

2 Gud rejser sig,

hans fjender spredes,

og hans modstandere flygter for ham.

3 Som røg vejres bort,

og som voks smelter for ilden,

går de uretfærdige til grunde foran Gud.

4 Men de retfærdige jubler og glæder sig, de fryder sig i glæde for Guds ansigt.

5 Syng for Gud, lovsyng hans navn,

byg vej for ham, der rider frem i ørkenen; Jahve er hans navn, fryd jer for hans ansigt! 6 Faderløses fader og enkers forsvarer

er Gud i sin hellige bolig.
(1) Stat op i Gry, min Gud! stat op! Adspredes, flygt, du Fiende-Trop!

Lær, hvad det er at grue!

Forsvind som Røg i Luftens Skiød!

Hensmelt som Vox for Ild og Glød!

Kan du Guds Ansigt skue?

(2) Op, glædes Alle, glædes nu

Og kommer Sorg ei meer ihu,

Retsindige og Fromme!

O, bryder flux i Lov-Sang ud,

For eders Herre, eders Gud

Ved Navn at ihukomme!

(3) Saa Haand paa Værket! nøler ei

Men baner for den Konge Vei,

Som farer paa det Jævne!

Han er de Faderløses Trøst

Han hører naadig Enkens Røst,

Og han har Guddoms-Evne.

Så vidt følger Grundtvig den gammeltestamentlige salme. Han gendigter trofast næsten hvert ord og i hvert fald (tilsyneladende) hele meningen. Det gammeltestamentlige billede med den sejrende konge er bevaret og omsat til moderne vesterlandsk poesi. Og sådan bliver det egentlig ved, resten af salmen; Grundtvig er meget teksttro i sin gengivelse. Den kristelige »forvending « sker så at sige mellem linjerne. Man kan sige, at Grundtvig også hér, fuldstændig som vi kender det fra den nytestamentlige brug af Det gamle Testamente, 
læser den gammeltestamentlige salme som en Kristus-salme. Grundtvig anlægger en bibelsk-teologisk linje, der er en videreførelse af såvel Det nye Testamente som af den oldkirkelige liturgi - jeg tænker her fx på anvendelsen af Es 53, digtet om Herrens lidende tjener, som jeg nævnte ovenfor. ${ }^{9}$

Den kristelige forvending af Sl 68 sker mellem linjerne, og det helt bogstaveligt mellem linjerne i den gammeltestamentlige tekst. Grundtvig indfører ganske simpelt en kristologi i forlægget. Han bevarer, næsten fuldstændigt, forlægget og indføjer så kristologiske temaer. De første to eksempler finder vi i strofe $4-5:^{10}$

7 Gud giver de ensomme et sted at bo, han fører fanger ud og giver dem lykke, kun de genstridige skal bo i det nøgne land. 8 Gud, da du drog ud i spidsen for dit folk og skred frem i ødemarken, Sela

9 da skælvede jorden, himlen dryppede af regn foran Gud, Sinajs Herre, foran Gud, Israels Gud.

$10 \mathrm{Du}$ lod regnen strømme rigeligt, Gud, du sørgede for dit udpinte land.

11 Der fandt dit folk en bolig, i din godhed sørgede du for de hjælpeløse, Gud.

12 Herren lader sit ord lyde, stor er skaren af kvinder med glædesbud.
(4) Han låner Huus til hver Forladt Af Lænker Han udløser brat,

Og hjelper op af Grave;

Til Marken gold den Herre god Udspringe bød en Naade-Flod, $\mathrm{Nu}$ bli'r den som Guds Have!

(5) Den fylder han med Liv og Lyst,

Og planter for de Arme Trøst, Som de har længdes efter; Og dem, som bare Jule-Bud, Indskyder Du, al Naadens Gud! Et Ord med Kampe-Krafter!

Det væsentlige hér er selvfølgelig de to helt tydelige Kristus-allusioner. Kristus er den, der »hjelper op af Grave« i strofe 4. Den gammeltestamentlige salmes strafmotiv, »kun de genstridige skal bo i det nøgne land « (v. 7b), må her vige for en fortolkning af billedet i den foregående linje i GT-salmen. »Han fører fanger ud og giver dem lykke« må for Grundtvig naturligt føre til tanken om den dødes opstandelse.

Endnu tydeligere er allusionen $\mathrm{i}$ anden del af strofe 5. For det første selve ordet »Jule-Bud«, og for det andet henvisningen til Ordet, der har »Kæmpe-Kræfter«. Det turde være overflødigt at gøre opmærksom på, at dét ord er Kristus selv. Men selve begrebet »Ord « har Grundtvig fra sit gammeltestamentlige forlæg. Han broderer vi- 
dere på det, og han specificerer det. Man er næsten ved at kunne sige, at Grundtvig her gør vold på sit forlæg, som han jo ellers har fulgt tro. Men han gør det - selvfølgelig - med vilje. Hvad jeg tænker på er, at det ord, Herren lader lyde i GT-salmen, er ordet, sejrsbudskabet: »Hærenes konger er på hastig flugt « (v. 13). Det billede forsvinder hos Grundtvig sammen med den »husets frue «, der i S1 68,13 b fordeler byttet. Dette halvvers: »husets frue fordeler byttet « forvandles hos Grundtvig til flg.:

I Herrens Lyst-Huus Bytte godt Man deler ud, til Fiendens Spot,

Sig Smaa til Stort nu sove; (strofe 6)

Flere ting kan iagttages her. For det første, at både »Lyst-Huuset « og de små, der kan sove sig til stort, er Grundtvigs egen opfindelse; de findes ikke i GT-teksten. Og for det andet, at Grundtvig her giver sin selvstændige fortolkning overfor forklaringerne i Christian VIs Bibel. Dér lyder v. 12-13:

Herren skal give sin tale; de som bebude, ere en stor hær.

Hærskarernes konger skal flye, ja de skal flye, og hun som boer i huset skal uddele rov.

Hertil forklares, at »de, som bebude, « er dem, der forkynder evangelium, og at »hun, som boer i huset« er »Christi menighed.« Denne fortolkning vælger Grundtvig altså at se stort på, ja springer den over.

I øvrigt kan man bemærke en stilistisk forskel mellem forlæg og gendigtning, nemlig, at Grundtvig, i modsætning til salmen, hér pludselig henvender sig direkte til Gud:

Og dem, som bære Julebud,

Indskyder $d u$, al Naadens Gud!

Et Ord med Kæmpekræfter (min fremhævning)

Endnu et par steder ser vi mindre forandringer i Grundtvig-teksen i forhold til forlægget. Jeg kan ikke lade være med at undre mig over den ændring, Grundtvig foretager i strofe 4. Den gammeltestamentlige salme rekurrerer her til ørkenvandringen, hvor det siges: 
Gud, da du drog ud i spidsen for dit folk

og skred frem i ødemarken, Sela

da skælvede jorden,

himlen dryppede af regn foran Gud,

Sinajs Herre,

foran Gud, Israels Gud (v. 8-9).

Men i strofe 4 bruger Grundtvig et andet frugtbarheds- og skabelsesbillede, kilden, der springer frem i Eden (1 Mos 2,6):

Til Marken gold den Herre god

Udspringe bød en Naade-Flod,

$\mathrm{Nu}$ bli'r den som Guds Have!

Hvorfor Grundtvig foretager denne ændring i billedsproget, véd jeg ikke; svaret på dette spørgsmål ligger hos Grundtvig. Men jeg skal antyde en mulig forklaring. Billedet henviser naturligvis til dåben, som Grundtvig ser som nyskabelse; måske har det ikke faldet ham ind, at også det gammeltestamentlige billede indeholdt et skabelsesmotiv. Han har så ganske simpelt forandret ét vandbillede til et andet. At disse to vandbilleder i Det gamle Testamente er indbyrdes variable, er et forhold, der egentlig ikke angår tolkningen af Grundtvigs salme, ja virker forstyrrende herfor. ${ }^{1}$

Påfaldende er det også, at Grundtvig så at sige springer den gammeltestamentlige salmes v. 22-24 over. Måske har de simpelthen været for blodige for ham; eller måske har deres billedsprog ligget for langt fra den tematik, Grundtvig arbejder i, nemlig Kristi sejrrige sprængning af Helvede og undertvingelse af Dødens magt.

Grundtvig slutter sin kristelige gendigtning af Sl 68 med en opfordring til sin læser om at se og forstå sammenhængen mellem Det gamle Testamente og den kristne kirke. Strofe 13 kan betegnes som et program:

Og stirrer vist paa Øster-Leed!

Der skinner Herrens Herlighed,

i Skyerne Han svæver!

Israels Gud, saa vennehuld,

i hver sin Helgen underfuld,

sit Folk op til sig hæver.

Jeg må indrømme, at jeg ikke finder betydningen af strofens næstsidste linje umiddelbart klar. En mulig forståelse er, at de omtalte 
helgener er repræsentanter for de enkelte folkemenigheder, som altså har formidlet, at folkeslagene bliver til Guds folk, den Gud, der oprindeligt var Israels Gud.

Ganske tydeligt er det derimod, at der for Grundtvig - og det bør ikke overraske - if. dette program ikke findes nogen kvalitativ forskel på Det Gamle og det Nye Testamente. Israels folk er også den kristne menighed - Israels Gud er den treenige, som han viser sig som Faderen og Sønnen. Det ligger, som vi har set, i tidens teologi; men det expliceres tydeligt af Grundtvigs opbygning af Sangværket efter de 7 folkemenigheder.

\section{Noter:}

* Forelæsning på Præsternes Studiedag, Center for Grundtvigstudier, Aarhus Universitet 1. maj 1995, let revideret.

1 Det vil i det følgende være nødvendigt at anvende eksegetisk fagterminologi. Betegnelser som »traditionshistorisk, interpretationskritisk, formkritisk og Sitz im Leben« hører til inden for den såkaldt historisk-kritiske forskning, som den drives ved de eksegetiske universitetsinstitutter. Læsere, der ikke er fortrolige med terminologien, henvises til opslag i fx Gads Danske Bibelleksikon eller Gads Bibel Leksikon, der udkommer primo 1997.

2 Biblia Hebraica er den tekstudgave, som en moderne, videnskabelig oversættelse af den gammeltestamentlige tekst bygger på, men for den sags skyld også den Resen-Svanningske oversættelse, som lå til grund for Christian VIs Bibel, den oversættelse, Grundtvig og hans samtid har kendt (se n. 6 nedenfor). Jeg citerer fra den nu autoriserede danske oversættelse, der således af praktiske grunde træder i stedet for en direkte sammenligning med den hebraiske grundtekst. I $\varnothing v r i g t$ gør det i flere tilfælde ikke den store forskel, hvilken af de to oversættelser, der benyttes, men se dog nedenfor s. 12 og 17.

3 Nikolaj Frederik Severin Grundtvig, Sang-Vark til den danske kirke I, fotografisk optryk, G.E.C. Gad, København 1982.

4 Brev til Ingemann, 22. sept. 1837, Grundtvig og Ingemann, Brevvexling 1821-1859, udg. Sv. Grundtvig, Kjøbenhavn 1882, s. 198.

Jørgen Elbek, Grundtvig og de graeske salmer, København 1960, s. 7-8. 
6 Grundtvig-forskerne er ikke ganske sikre på, hvilken udgave, Grundtvig har brugt, 1759-udgaven af Christian VIs bibel eller 1787-oplaget, som Constance Leth forærede ham i 1807. Imidlertid findes der ikke væsentlige forskelle mellem de to udgaver, så spørgsmålet er i sidste ende ligegyldigt, især sammenholdt med, at Grundtvig formodentlig ofte har citeret efter hukommelsen, måske også sine steder fra Luther-biblen 1550/1589 og senere (således Bodil Ejrnæs, mundtligt).

7 Se hertil nærmere Bodil Ejrnæs, Skriftsynet igennem den danske bibels historie - således som det afspejler sig $i$ bibeloversattelserne og $i$ de kommentarer der ledsager bibelteksterne, (Forum for bibelsk eksegese 6), Museum Tusculanums Forlag, København 1995.

8 I de gammeltestamentlige salmer, eller generelt i gammeltestamentlig teologi, finder man ikke tanken om kødets opstandelse og det evige liv.

9 Jf. Knud Jeppesen, »Herrens lidende tjener i historien og traditionshistorien, Tekster \& Tolkninger - ti studier $i$ Det gamle Testamente (udg. K. Jeppesen og F.H. Cryer), Anis, Århus 1986, s. 113-26; M. Müller, Kirkens forste Bibel. Hebraica sive Graeca veritas?, Anis, Frederiksberg 1994, s. 114-134.

10 De kursiverede dele af Grundtvigs digt er dem, der ikke har noget direkte forlæg i den gammeltestamentlige salme.

11 For hjælp i disse overvejelser skylder jeg deltagerne i Præsternes Studiedag en stor tak. 